\title{
Female Archetypal Will in Nathaniel Hawthorne's The Scarlet Letter, Rani Manicka's The Rice Mother, and Sophie Treadwell's Machinal
}

\begin{abstract}
Email: toorh2321@hotmail.com

This paper examines literary archetypes as symbolical representations of real people in fiction in Nathaniel Hawthorne's The Scarlet Letter, Rani Manicka's The Rice Mother, and Sophie Treadwell's Machinal. They carry on the human perception of natural or human phenomenon. Feminism is one of the most resonating archetypal issues in literature. The depiction of women suffering and hardships is a central question aroused by critics who deal with the issue of female identity; and how female can prove strong in patriarchal societies. Women suffering could also provide new perceptions of female position and its possible elevation. Therefore, literary archetypes offer a sound and compelling image of females in literary works. In this regard, the perception of women in hard conditions would result in probable solutions for their bad conditions. Such conditions are caused by society which does not attend to women's needs and practice marginalization against them. However, women can be strong enough to support their families and break the traditional judgement of them as inferior to men. Accordingly, fiction is one possible way of exposing women's tremendous will to change their position in society. Thus, the purpose of this essay is to study women heroic will to in Nathaniel Hawthorne's The Scarlet Letter (1850), Rani Manicka's The Rice Mother (2002), and Sophie Treadwell's Machinal (1993). The heroines of these works have a strong will be prove their position as being capable of doing men's stuff, such as work and family support.
\end{abstract}

Hilalah Dughayyim Aldhafeeri

University of Hafr Albatin, Saudi Arabia

Key Words: Archetype, Feminism, Heroism, Repression, Scapegoat

DOI: $10.7176 /$ JLLL/66-09

Publication date:March $31^{\text {st }} 2020$

\section{Introduction: Feminism}

Feminists, such as Estella Lauter and Carol Rupprecht, believe that the more fairy tales that prevail about heroic men and needy women. The more difficult it will be for women to change such stereotyped role expectations as: "Men are brave and clever; they hunt and solve problems, whereas women stay home, look after children, create a pleasant home life-and obey" (55). However, Jung also wrote that femininity is associated with "feelings of inferiority" (82). Since his work has predominantly been interpreted by men who are mostly against abolishing patriarchal structures, these concepts have helped men enhance patriarchal myths and undervalue the merits of women as well as their experience and power: "the archetype [of women] must be seen not as "an image whose content is frozen" but as "a feminist tool for re-examining and re-evaluating patterns in women's experiences" (Enns 60). The mother, the animus and the independent woman as illustrated by women differ from that which is illustrated by men and the independent woman was largely ignored by Jung (312).

Moreover, Hester's marriage in conformity with the tradition is poor and mean compared to her love affair. In the prison interview, Hester reminds her husband of the first date she had "felt no love, nor feigned any." Hawthorn, in The Scarlet Letter, was writing his version of the traditional story of passion. Actually the patent features of the archetype which emerge in the novel make his departure from the tradition appear all the more radical and dramatic. After her second meeting with her husband, Hester knows that she hates him. "But Hester," comments the narrator that "ought long ago to have done with his injustice. What did it betoken? Had seven long years under the torture of the scarlet letter, inflicted so much of misery and wrought out no repentance?" (175-76). Hester should be deemed as a good woman in some aspects, and further shows the harshness of cruelty of Puritan society. Hester's position represents the society's discrimination. She, later, leaves the society and lives alone to fulfil her will. She does not repent or care for the society. 


\section{Repression}

Nineteenth-century patriarchal culture gives women a role and encourages repression of everything outside that realm (Estés 15). Therefore, women are left to embrace the spiritual and home-life relegated to them while the idea of intuition, sexuality, sensitivity, and emotion is devalued in men as well as in women: "The repression of femininity, therefore, affects mankind's relation to the cosmos no less than the relation of individual men and women to each other" (Boag 123). The patriarchal culture has given the governor the need to control his environment, trying to perfect or change those things he does not understand. He cannot accept, on faith, anything that is out of the realm of the head (Abu Jweid and Sasa 62). Patriarchal cultures ignore the idea of a combined reality that insists on both sides of one's self being acknowledged and dealt with. Society ignores the disorderly, chaotic realm and fears its appearance. We see the separation of opposites and fragmentation of the whole in The Scarlet Letter amplified to proportions it is hard to miss. Woman, as she exists in the archetypal feminine, is exiled and now "women must be good, nice, nurturing, and receptive in the orderly, wish fully thinking, and rolatric world" (Whitmont 61). When women break this mould, as in the case of Hester Prynne, the transgressor "is excluded from the community in proportion to the severity of the non-conformism. A cordon sanitaire is erected against him in order to protect the group from infection, from the evil or danger he has stirred up" (Whitmont 63). Hester Prynne is excluded from Hawthorne's Puritan community because her transgressions are not hidden and therefore force a confrontation within that community. She lives in the outskirts of the township, at the edge of the forest and at the edge of the ocean. These boundaries accentuate Hester's isolation. This isolation is equal to death, as Hawthorne shows us by the proximity of the graveyard to the jail. Boston is described by Hawthorne as "this roughly hewn street of a little town, on the edge of the Western wilderness" (57).

It is the very inconvenient events and humiliation that Hester has undergone that serve to wrap her in a halo and separate her even further from the crowd. Though no longer in prison, she is still within a sphere of her own. The scarlet letter, which she must wear on her bosom for the rest of her life "had the effect of a spell, taking her out of the ordinary relations with humanity, and inclosing her in a sphere by herself" (54). Furthermore, her punishment is expressed in violent terms. Reverend Wilson relates an argument he had with Dimmesdale about whether to force Hester to confess in public: "Speak to the woman, my brother," said Mr. Wilson. "It is of moment to her soul, and, therefore, as the worshipful Governor says, momentous to thine own, ill whose charge hers is. Exhort her to confess the truth! The Reverend Mr. Dimmesdale bent his head, silent prayer, as it seemed, and then came forward" (54). Hester's explanation to herself is that New England was the scene of her crime; therefore, it should also be the scene of her punishment. As shame burns inside of her, she searches for companionship or sympathy, but to no avail:

What she compelled herself to believe what, finally, she reasoned upon as her motive for continuing a resident of New England was half a truth, and half a self-delusion. Here, she said to herself had been the scene of her guilt, and here should be the scene of her earthly punishment; and so, perchance, the torture of her daily shame would at length purge her soul, and work out another purity than that which she had lost: more saint-like, because the result of martyrdom. (64-65)

Similarly, Lakshmi's story begins when she is conned into an arranged marriage with Ayah who apparently owns a 'rich' business in the land of Malaya. At the warm age of fourteen, she dealt with this painful truth while separated from her beloved mother in India and attempts to raise her five children to the very best she could, often being very selfish and forcing her ambitions on her children. The problematic of gender are deduced to a stage where women are in absolute control of her fate and destiny: "Until, that is, at the age of fourteen when the first drop of the menstrual blood proclaimed me suddenly and distressingly into a grown woman" (9). Besides, deciding for themselves on issues related to education, career and marriage: "Unlike boys, girls didn't have to go to school in our day except for the two hours of every evening when mother taught reading, writing and arithmetic, I was left mostly to run wild" (9).

Lakshmi, a child bride, is soon ripped away from mother and home to live with an older man she neither knows nor loves: "I turned around and kissed my mother...that we would never meet again for the rest of our lives" (22). When she arrives at her new home, she promptly discovers that Ayah is not rich at all, but a clerk who had borrowed a gold watch and a servant to trick Lakshmi's mother. Not only is Lakshmi's husband old and ugly, he is also weak, lazy, repetitive and widower: "Your new husband is a widower and has two children..." (14).

In this respect, the relationship between Lakshmi and her mother is based on material purposes. She does not want to abide by the social traditions. Her mother forced her to marry an old man because he is rich. But, by time, she discovers that he is a liar. He is very poor and he wants to marry her by any means. She oppressed by the 
patriarchal society that pushed her in her bitter fate. Lakshmi is an archetype of the victim woman who deceived by materialistic society in a general view.

Moreover, in Treadwell's Machinal and out of this event came the powerful, demanding drama Machinal, a woman's role during this era in history is confined and regimented to wife, mother, housekeeper, and sexual partner. Love is considered unnecessary, and may be young woman are trapped in their dependent status, living a hellish life in a loveless marriage: "confronting a phalanx of male characters with the power to determine her life. Again and again Helen complaints of claustrauphobia, a motif of entrapment that runs as a common thread through [her contemporaries' plays]" (Malinowski viii).

The young woman forced financial dependency upon her boss who gives her proposal for marriage. She also encouraged by her mother to marry a wealthy man. Helen tries to explain that she does not love George, and her mother responds: "Love! - What does that amount to! Will it clothe you? Will it feed you? Will it pay the bills?" (17). Helen married her boss whom she found repulsive. The major theme is the role of marriage and a woman's dependant status on her husband's wealth.

The young woman lives in a patriarchal society which "has been described as a general structure in which men have power over women" (Molly 198). The play shows the stages of her life (daughter - wife - mother) and has shown her disgust and distress from the rigid culture. Through the play portraying the strained relationship with her mother, husband, baby girl and the cold, mechanical world she feels so alienated from. When her husband (George) asked her to sleep with him she cried:

HUSBAND (stars toward her-stops. The room is in shadow except for one dim light by the bed. Sound of girl weeping). You crying? (Sound of weeping.) What you crying for? (Crosses to her.) YOUNG WOMAN (crying out). Ma! Ma! I want my mother! HUSBAND. I thought you were glad to get away from her. YOUNG WOMAN. I want her now - I want somebody.

HUSBAND. You got me, haven't you?

YOUNG WOMAN. Somebody - somebody -

HUSBAND. There's nothing to cry about. There's nothing to cry about. (26)

In concern with the concept of neurosis, Freud wrestled both actual neurosis and psychoneurosis start from the same point, namely the experience of an internal pressure that has not been, or is unable to be, psychically elaborated (Geyskens 15). In the case of actual neurosis, the arousal continues to be active on the somatic level (Abu Jweid, 2016: 42). So neurosis is the manifested model in Helen character. We observe that in her speech with the doctor and nurse when she was in a hospital. She gives birth to a newborn girl. She shocked and depressed, feeling that position she finds herself (being wife and mother) was pushed upon her by society.

DOCTOR (at chart). Milk hasn't come yey?

NURSE. No, Doctor.

DOCTOR. Put the child to breast. (YOUNG WOMAN - 'No-no'! - Riveting machine.) No) Don't you want to nurse your baby? (YOUNG WOMAN signs 'No'.) Why not? (No response.) These modern neurotic women, eh, Doctor? What are we going to do with 'em? (YOUNG DOCTOR laughs.

NURSE smiles.) Bring the baby!

YOUNG WOMAN. No!

DOCTOR. Well - that's strong enough. I thought you were too weakto talk - that's better. You don't want your baby?

YOUNG WOMAN. No.

DOCTOR. What do you want?

YOUNG WOMAN. Let alone - let alone.

DOCTOR. Bring the baby.

NURSE. Yes, Doctor - she's behaved very badly every time. (29)

Helen's sense is of entrapment by surrounding the stage with an imposing wire cage. Anna Waston's lighting design also contributes to this feeling of isolation, using spots to separate the young women from everything else, adding to her desire to be both left alone and free (Billig 23). She sees how society confines her, and how her husband unconsciously dominates her every decision, and she feels that there is no escape.

\section{Shadow}

The gender oppression towards Helen leads her into the shadow which reveals her weaknesses. George W. Davis writes: 
Shadow represents that which is excluded from consciousness because it is threatening painful, embarrassing or destabilizing. The shadow may be experienced individually or collectively. ... The shadow has too often been split off in Western thinking and we know, psychologically, that whatever is split off reinsinuates itself through behavioural eruptions or projections onto others. (143)

Helen is being an entrapment woman in the patriarchal society leads to her struggle to be free. Helen desires a progressive, modern feminist sense of freedom that she cannot find in her world and her life. She yearns to be independent, leading her own life, and marries someone she loves. Though she fails to achieve her goals, she finally frees herself through death: "JUDGE. You confess you killed your husband? YOUNG WOMAN. I put him out of the way - yes. JUDGE. Why? YOUNG WOMAN. To be free" (75). She spirals into a ridiculous, dead-end choice, murdering her husband to liberate herself and save her husband (George) from the pain of divorce. When the judge asks why she did not simply divorce her husband and, ironically, she responds: "Oh I couldn't do that!! I couldn't hurt him like that!" (75). Helen was punished for seeking fulfilment and freedom by further oppression of her character. In the last breath she screams: "Submit! Submit! Is nothing mine?" and asks the priest if she will ever find peace, if she will ever be free. And in a final statement, Helen cries out her final words: "Somebody! Somebody_ _ but is cut short by the electric chair. Here, "Helen's collaboration with the defence lawyer's story gives way to the unavoidable collaboration with the prosecutor's story. Neither... represents her own experience or intentions" (Tournier 171). Therefore, Helen is the archetype oppressed, crumbling under external controls that bear down on her such as the social expectations of finding a husband and having children. In this fashion, Helen is embodies the archetypal will to be strong in her adverse society.

\section{Heroines}

Hester Prynne is the heroine in the story. Throughout her entire ordeal, she was always courageous. She could have easily given up, but she did not. Despite all the criticism she encountered, she never gave up. She stayed strong so that she could raise her daughter, Pearl. Even though Hester sins against God, she is a woman who survives the horrendous trials of a "Puritan" society-the society that wants to be a Utopia among imperfect people. From her horrendous trials, Hester gains strength, courage, and her lost love. She is a woman accused of committing adultery that is considered a grave sin among a Puritan society-Utopia. Since Hester sinned against God, the judge, decide to condemn Hester from paradise. In other words, Hester would not be considered a Puritan. However, Hester does not care about the judgement of the magistrates. Instead, she knows that God will judge her:

"With all my heart! Why, Mistress, I hear good tidings of you on all hands! No longer ago than yesterve, a magistrate, a wise and godly man, was discoursing of your affairs, Mistress, Hester, and whispered me that there had been question concerning you in the council. It was debated whether or no, with safety to the common weal, yonder scarlet letter might be taken off your bosom. On life, Hester, I made my entreaty to the worshipful magistrate that it might be done forthwith!"; "It lies not the pleasure of the magistrates to take off this badge," calmly replied Hester. "Were I worthy to be quit of it, it would fall away of its own nature, or be transformed into something that should speak a different purport." (132)

The judge decides that letter should be uses as a sign of her sin, in purpose of a living sermon against sin. They think that this letter will restrain Hester's rebellious passion because it threatens their civil system. As the community reinterprets the scarlet letter, however, Hester again has an identity thrust upon her by her fellow town's people. So the scarlet letter "A" does not supply its purpose, and it does not suppress Hester from the Puritan society. Firstly, she enlarges the letter A for everybody to see on her bosom. Secondly, Instead of hide or making the "A" a simple letter, she embroiders the letter with complex designs of gold. Besides she wants to show the scarlet letter, light, to everyone. By doing this, she wants to let people know that all people sin. Hawthorne depicts this as follows:

... if truth were everywhere to be shown, a scarlet letter would blaze forth on many a bosom besides Hester Prynne's? Or, must she receive those intimations--so obscure, yet so distinct--as truth? In all her miserable experience, there was nothing else so awful and so loathsome as this sense. It perplexed, as well as shocked her, by the irreverent inopportuneness of the occasions that brought it into vivid action. (69)

Hester crosses the threshold as physically free into the world of the community entering, once again, as a member of this society. She crosses this boundary from the confinement of prison to the society that condemns her. Although she is an outcast, however she remains able to support herself due to her uncommon talent in 
needlework. She chooses, as her home, a small cottage: "on the outskirts of the town, within the verge of the peninsula, but not in close vicinity to any other habitation" (81). Hester's cottage borders the town, the sea, and the forest but "... its comparative remoteness put it out of the sphere of that social activity which already marked the habits of the emigrants ..." (81). She isolates herself by choosing a dwelling that borders both civilization and nature. Spiller asserts that "Everywhere bordering on New England is another land, whose geography human beings imagine but cannot chart" (431).

Hester confronts her "realities" and discovers a new self that does not fit with her old conceptions of herself. She is successfully cut off from the Puritan community. Hester's isolation from the rest of society is important to the Puritans because of the danger they sense within her. Hawthorne's Puritan community sets its rules and standards, and they identify with their definition of absolute good. In this crowd Hester has broken the code of moral law and the "individual dissenter is, by definition, evil and a public enemy" (Whitmont,91). Besides, the writer informs us that her clothing "... seemed to express the attitude of her spirit, the desperate recklessness of her mood, by its wild and picturesque peculiarity" (53). Hester's feminine spirit will not be tamed by her time in prison or her humiliation.

So, Hester's improved reputation among the town's people would seem to speak to the community's generosity of heart, its wisdom and compassion. She becomes an advocate for women and takes on a role in the community similar to that of a minister: she cares for and attends to the spiritual needs of her fellow human beings.

She was self-ordained a Sister of Mercy; or, we may rather say, the world's heavy hand had so ordained her, when neither the world nor she looked forward to this result. The letter was the symbol of her calling. Such helpfulness was found in her, - so much power to do, and power to sympathize, - that many people refused to interpret the scarlet A by its original signification. ... "It is our Hester, - the town's own Hester, - who is so kind to the poor, so helpful to the sick, so comfortable to the afflicted!" (126-127)

Hester represents a contrast as she exudes the feminine nature this patriarchal culture has tried to excise from their world. Thus, she is the archetypal notion of women's strong will to be equal to men. Likewise, Helen Jones in Machinal is being portrayed as an enigmatic and yet the most disappointing character in the play. She is what Carl Jung would have depicted as the trickster archetype. The trickster archetype, just like the character Helen, "relish the disruption of the status quo, turning the Ordinary World into chaos with their quick turns of phrase and physical antics" (Coster 10). Helen is considered as the heroine of this play for the live revolves around her. In addition she could achieve her dream and freed herself. She also broke the rigid culture that regarded stable in the society. Throughout the play, Helen is not a very surprising character at first, knowing that she is a beautiful innocent lady but when her character turns around unknowingly, that reflects her unspoken desire for transformation and successful dealings. She confuses not only the characters (Machinal) in the play but also leaves the readers in dazzle and confusion as to whose side she is on. According to Jung, a trickster will use "laughter and ridicule to make characters see the absurdity of the situation, and perhaps force a change" (Coster 10). George Jones, a kind, flabby-handed, slovenly man, has asked Helen to marry him. She does not know how to answer. Helen wants nothing more than to be free of her terrible job, but the answer is a loveless marriage to an unattractive, unappealing man. However, as soon as Helen's mother discovers that the man is wealthy, she changes her tune, telling her daughter to marry him straightaway.

MOTHER. Who is he? Where did you come to know him?

YOUNG WOMAN. In the office.

MOTHER. In the office!

YOUNG WOMAN. It's Mr. J.

MOTHER. Mr. J.?

YOUNG WOMAN. The Vice-President.

MOTHER. Vice-President! His income must be - Does he know you've got a mother to support?

YOUNG WOMAN. Yes.

MOTHER. What does he say? 
YOUNG WOMAN. All right.

MOTHER. How soon you going to marry him? (17)

Helen is the woman archetype that represents the materialistic society in a general view. She tends to be indecisive when it comes to marriage and too enthusiastic when wealth and power are under her eyelashes. She is looked as a bad motivation for women because her characteristics are not seen as a good guidance. Readers will know that she marries George H. Joens in response to his wealth and power, and not purely out of love. Therefore, Helen is the representation archetype of materialistic women in which men must be aware of. Besides, Helen as a heroine is a type, but as her unconscious is revealed through free-association soliloquies

Equally, Lakshmi's marriage to Ayah was planned by her mother. She encouraged her daughter and encourages her that Ayah is a business man. She arranges a marriage with what she believes to be a wealthy man: "Lakhsmi, I have accepted a marriage proposal for you... he is of a better caste than we are and he lives in that rich land called Malaya" (page 13). She married Ayah in non love "Fear coursed through my child's body at the thought of that man being my husband....love for me became the worm in the apple" (17).

\section{Lakshami’s Heroism}

In the text, The Rice Mother the hero is Laskhmi. Though, the story expresses details the struggles of a Matriarch determined to advance her children, and the scars her ambition leaves on the family. Lakshami was the strong woman who could overcome the challenges encounters her. When she knew her husband is futile she accepted the real situation and struggled to survive her family. Lakshami breaks the social barriers and tries to find good job. In the course of the events, she becomes a good worker. She works hard and supports her mother and family. She has an extraordinary story to tell of their struggle to come alive: "I should tell you straight away how incredibly special she was," is Lakshmi's breathless aside when her first daughter is born: "Gorgeous, clever, precious and indisputably my favourite," she says of her first son, and "she was a good, good baby with enormous, shining eyes," of her second daughter. Lakshmi holds the burning dreams of her children and grandchildren in her strong hands and passing years will not diminish her courage and strength in defending them. Ayah is the provider, for the most part a decent man who looks into her financial and domestic needs. So Lakshmi becomes a formidable matriarch who improves and takes control of a sprawling household that soon includes six children of her own.

Lakshmi encounters her mother's fault in concern with her marriage to Ayah in patience and enduring. She hides the dissatisfied and reveals the willing. During the first time she sees her husband is at her wedding, and he turns out to be old and ugly. Then she is dressed up, decorated with roses and jewels, and launched on to the marriage market. And yet there is something touching about the little girl who draws herself up bravely to meet his gaze and pretends to her mother that things are grand.

By the age of nineteen Lakshmi is a mother of five children. She was very proud of her children yet very demanding her family is torn by feelings of awe bordering on reverence for their imposing mother, yet hate for her tenaciousness in planning their futures for them. During World War II to the torture of watching some of her children yield to life's most terrible temptations, she rises to face every new challenge with almost mythic strength. Towards the moment of horror as the soldiers burst into the house and drag the girl away. "She trembled inside my grasp like a small dying mynah bird," says Lakshmi as her daughter is dragged from her. "War for their mother is an opportunity, a soothing treatment to heal from the traumatic experience, and an escapism to resist and find ways to survive. Thus, she has taught her children to face the difficulties by making profits and opportunities out of the wretchedness of war". (Amran 147) In this sense, Lakshmi's heroism is her ability to struggle and support her family. She does not feel inferior and marginalized. She defies her harsh life and works strenuously to affirm her strong will to be independent.

When we return to our empty, looted home after the Japanese invasion, Mother had to use more than half of her savings to replace everything that had been stolen. To her credit she took the disaster in her stride... The Japanese made us all very resourceful, but mother was an undefeatable force... The advent of the Japanese made Mother and entrepreneur, and she had quite a knack for it too (88).

In the above excerpt, we observe how the mother (Lakshmi) endured and struggled to survive her family. Consequently, the period has brought out the best in their mother, who learns to cope, and in turn, teaches her children some useful skills for survival. Lakshami is an archetype of the formidable managing and surviving woman for her family. 


\section{Scapegoat}

According to Northrop Frye, "The figure of a typical and random victim begins to crystallize in domestic tragedy as it deepens in ironic tone. We may call this typical victim the scapegoat. We meet a scapegoat figure in Hawthorne's Hester Prynne" (185). Hester becomes a scapegoat, and the public nature of her punishment makes her an object for voyeuristic contemplation; it also gives the townspeople, particularly the women, a chance to demonstrate - or convince themselves of - their own piety by condemning her as loudly as possible. She also plays the scapegoat when she takes on the scarlet letter. The scarlet letter represents not only Hester's sin, but also the sins of the other citizens that have also committed adultery. That is why some of the other townspeople looked away and blushed when she walked past them: "Those who had before known her, and had expected to behold her dimmed and obscured by a disastrous cloud, were astonished and even startled, to perceive how her beauty shone out, and made a halo of the misfortune and ignominy" (44). It was because they were ashamed of her. "This woman has brought shame upon us all, and ought to die" (43).

Rather than seeing their own potential sinfulness in Hester, the townspeople see her as someone whose transgressions outweigh and obliterate their own errors. Scapegoat of other women: made a living warning to others who are tempted to give in to unlawful impulses; a reminder that gives townspeople, especially the women, a chance to demonstrate or convince themselves if their own piety by condemning Hester as loud as possible:

"Make way, good people--make way, in the King's name!" cried he. "Open a passage; and I promise ye, Mistress Prynne shall be set where man, woman, and child may have a fair sight of her brave apparel from this time till an hour past meridian. A blessing on the righteous colony of the Massachusetts, where iniquity is dragged out into the sunshine! Come along, Madame Hester, and show your scarlet letter in the market-place!" A lane was forthwith opened through the crowd of spectators. Preceded by the beadle, and attended by an irregular procession of stern-browed men and unkindly visaged women, Hester Prynne set forth towards the place appointed for her punishment. A crowd of eager and curious schoolboys, understanding little of the matter in hand, except that it gave them a half-holiday. (45)

Hester remains either a scapegoat or a negative example. She is not allowed to receive forgiveness. This deprivation is the archetypal and patriarchal discrimination against her. She suffers from the society's unjust treatment. She seeks forgiveness midst a harsh society which does not give her any fair chance to be equal to men.

\section{Nature}

Nature, through Hester, takes on a life of its own. It is in the forest that Hester comes alive, her deepest being drawn out of the shadows and allowed to pour forth through her physical body. Her feminine nature is at its most vivid and her archetypal consciousness comes alive. Hester moves through the forest, its character is alive and communicative within her. Hester lives at the edge of the wilderness, but also at the edge of the community from which she has been hated. She is bounded on all sides by something from which she is separated, something from which she is not a part. She lives on the edge of the forest, the community, and the ocean. Yet Hester is isolated, with only Pearl by her side. Hester moves from one physical realm to another within a sphere of her own. The writer uses nature to represent the unknown or the dark unconscious. The repression of the feminine here is the unwillingness or inability to see the unconscious and the idea of nature. The shadow that is repressed is alive and well whether it is confronted or ignored.

As Hester's wild nature refuses to be subjugated by her time in prison and the essence of the community itself, this wild rosebush stubbornly grows amidst the weeds and grim qualities of the Puritans. But just outside the prison-door "... on one side of the portal, and rooted almost at the threshold, was a wild rose-bush, covered, in this month of June, with its delicate gems" (39). This sign of nature, this "wild" beauty stubbornly grows within this stifling society. Nature invades the Puritan world of grim sternness. This sight of nature, not to be overwhelmed and subdued, is "on the threshold of our narrative, which is now about to issue forth from that inauspicious portal" (40). And so enters the indomitable Hester Prynne.

Further, nature itself seems to be signalling that what is to take place will not be a simple illumination of truth (Abu Jweid and Kaur 9). The sunlight seems to be avoiding Hester deliberately as she and Pearl walk through the forest. So the light symbolizes truth, then this strange natural phenomenon appears to be suggesting that Hester is avoiding, or will not find, the "truth" that she seeks to convey to Dimmesdale: "Mother," said little Pearl, "the sunshine does not love you. It runs away and hides itself, because it is afraid of something on your bosom. Now, see! There it is, playing a good way off. Stand you here, and let me run and catch it. I am but a child. It will not 
flee from me--for I wear nothing on my bosom yet!" (144). Besides, the sun shines on the couple when Hester removes the scarlet letter, suggesting that nature, God, or both favour their plan: "It was strange, the way in which Pearl stood, looking so steadfastly at them through the dim medium of the forest-gloom; herself, meanwhile, all glorified with a ray of sunshine, that was attracted thither ward as by a certain sympathy. In the brook beneath stood another child, - another and the same, - with likewise its ray of golden light" (162). Hester's isolation in nature indicates her repulsion of her lack of social forgiveness.

Likewise, in The Rice Mother. The story is the explanation of the protagonist's social cultural background, origin, and nature of character both physical and personality: "I was born in Ceylon in 1916" (3). With nature, when she was determined to not extend her stay at her uncle's place in Negeri Sembilan because her Aunt's unkind comments about a sum of money that she had borrowed from her uncle some years back: "I resolved to leave that day, even if meant walking back all the way to Kuantan, carrying my children on my back...but I was very proud in those days... when my uncle returned... he reluctantly made arrangements for us to travel by boat... it was not the romantic place-the jungle, I had pictured it to be....the man enjoyed our jerk into terror, our hiss of horror..." (99-100).

Nature, here, embodies an escape for the heroine from her sufferings. She does not want to be in her society any more. Social bias against her allows her the chance to live in secluded natural places to live peacefully. Her isolated life exemplifies her repulsion of society. More important, she wants to prove her strength as a human being. She does not comply by the society traditions in order to be free of bias and marginalization. Therefore, she gains her will from being alone in natural places. Hester and Lakshmi isolated in nature as indication of their repulsion of their lack of social mercy. They are archetype of the strong women who resort to nature as a home for their loneliness.

\section{Conclusion}

This essay has focused on the female will in Hawthorne's The Scarlet Letter (1850), Manicka's The Rice Mother (2002), and Treadwell's Machinal (1993). The study has emphasized the bad conditions in society. The heroines of these novels suffer from emotional as well as social marginalization. Their social conditions contradict with their ability to be equal or free of male mainstream. In order to prove strong, the heroines do the same things which are done by their male counterpart. That is, some of the heroines could work to support their families and do domestic work in order to get by their lives. In essence, the heroines exemplify the female inferiority archetype in fiction in general.

My analysis, however, has focused on the strong aspect of the females in the selected works. The females are not inferior or weak. Instead, they are strong enough to be equal to men. I have accentuated the heroines' will to work and prove themselves as strong as men. Although the heroines are depicted in an inferior position, I have analyzed their endurance and fortitude while they are treated badly in their societies. The result of their negative treatment led their societies to ostracize them; and they are consequently cast out by their societies. In such condition, they are helpless. They do not find any source of aid for their lives. They also do not have a shelter for their sufferings. For this reason, I have highlighted their pursuit of life through work and isolation to get rid of their societies' prejudice.

\section{References}

Abu Jweid, Abdalhadi, and Ghada Sasa. "John Barth's "Dunyazadiad"”: The Parody of The Arabian Nights' Frame Tale. Jordan Journal of Modern Languages and Literatures 6.1 (2014): 60-77.

Abu Jweid, Abdalhadi. "The Fall of National Identity in Chinua Achebe's Things Fall Apart." PERTANIKA 23.5 (2016): 40-57.

Abu Jweid, Abdalhadi, Hardev Kaur. "War Allegory in Narayan Wagle's Palpasa Café." PERTANIKA 26.T (2018): 1-12.

Amran, N.A, and R.S Hashim. "Reading Japanese Occupation in Malaya in the Rice Mother Through the Lens of Social Memory." Asian Social Science. 9.7 (2013): 144-150. Print.

Billig, Michael. Freudian Repression: Conversation Creating the Unconscious. Cambridge, U.K: Cambridge University Press, 1999. Print.

Boag, Simon. Freudian Repression, the Unconscious, and the Dynamics of Inhibition. London: Karnac Books, 2012. Print. 
Davis, George W. Unfinished Heroes: The Abandoned Hero's Journey of Contemporary Business Leaders. Carpinteria, Calif: Pacifica Graduate Institute, 2006. Print.

Estés, Clarissa P. Women Who Run with the Wolves: Myths and Stories of the Wild Woman Archetype. New York: Ballantine Books, 1992. Print.

Frye, Northrop. Anatomy of Criticism. London: Penguin, 2002. Print.

Hallenbeck, Kathy H. Completing the Circle: A Study of the Archetypal Male and Female in Nathaniel Hawthorne's the Scarlet Letter. Johnson City, Tenn.: East Tennessee State University, 2002. Print.

Hawthorne, Nathaniel. The Scarlet Letter. Great Britain: Oxford University Press, 2007. Print.

Lauter, Estella, and Carol Rupprecht. Feminist Archetypal Theory: Interdisciplinary Re-Visions of Jungian Thought. Knoxville: University of Tennessee Press, 1985. Print.

Malinowski, Bronislaw. Sex and Repression in Savage Society. London: Routledge, 2003. Print.

Manicka, Rani. The Rice Mother. New York: Viking, 2002. Print.

Spiller, Robert E. Literary History of the United States. New York: Macmillan, 1963. Print.

Tournier, Paul. Guilt \& Grace: A Psychological Study. New York: Harper, 1962. Print.

Treadwell, Sophie. Machinal. London: Royal National Theatre, 1993. Print.

Whitmont, Edward C. Return of the Goddess. New York: Crossroad, 1982. Print.

Zhou Molly Y. Supporting Multiculturalism and Gender Diversity in University Settings. Delton State College. USA. Published by IGI Global, 2015. Print. 